
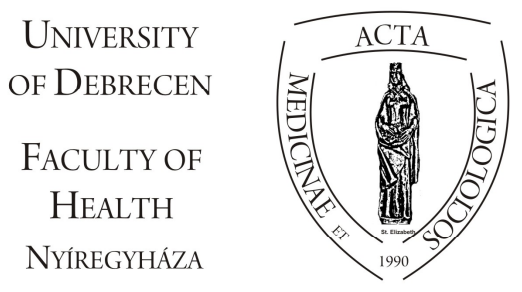

ACTA

MedSoc

VOLUME 8.

2017

\title{
A bokortanyák helyzete és az újabb kihívások
}

\section{Bácskainé Pristyák Erika}

\author{
Nyíregyházi Egyetem, Turizmus és Földrajztudományi Intézet
}

\begin{abstract}
The situation of 'bokortanyák' and the new challenges. Since the end of communism the situation of grouped farmsteads (bokortanyák) has changed in a variety of ways; they have significantly differentiated, this generally uniform type of settlement of the Great Hungarian Plain has become fragmented. The'bokortanya' is aspecial type of settlement, some examples of these can be found west of Nyíregyháza.

Around Nyíregyháza, - within a $10 \mathrm{~km}$ radius, 35 bokortanya with the population of 5,200 - these extreme changes can be observed both within the bokortanyak and between them. Their relationship with Nyíregyháza ranges from dormant settlements to independent, self-sufficient ones. Economic and political factors, the attitude of their 'mother' city, the attitude of locals all have some influence on their development. Nowadays it is not only and homogenously husbandry that provides the basis for a lot of families; however, cultivation of the land, keeping livestock still serves this purpose. The suburban lifestyle has become more popular as well. In addition to the unique,personal paths of life, these bokortanyak are strengthened by the communities, which have gained more importance due to the interdependent nature of the settlement.

On top of challenges presented by the peripheral characteristics of these places, there are also opportunities for recreational and touristic activities. The developments have taken many different forms; the viability of these settlements can be boosted by various factors.
\end{abstract}

Keywords: differentiation, civic organisations, challenges. 


\begin{abstract}
Absztrakt. A rendszerváltás óta eltelt időszakban változatosan alakult a tanyák sorsa, jelentős mértékben differenciálódtak, ez a jellegzetes egységes alföldi településtípus mozaikossá vált. Az alföldi tanyák kutatása terén a Homokhátság (Bács-Kiskun megye) a leginkább megvizsgált terület (Csatári 2005.) és ez innovatív térség is. Alapos külterületi állapotfelmérés történt Békés megyében is (Nagy, Dudás, Bodnár G., 2016.). Az alföldi tanyákon élő mintegy 200.000 fös népesség helyzete hasonló, sokféleség jellemzi, a területi különbségek mozaikosak. A nyíregyháza környéki tanyákon - mintegy $10 \mathrm{~km}$-en belül, 36 bokortanyát tekintve, 5200 fös népességgel -, még inkább megfigyelhetők e szélsőséges változások, egy-egy tanyabokron belül, és a különböző tanyák között is (Pristyák, 2011). Nyíregyháza népességének 5\%-a él külterületen, a városhoz való kötődésük változatos kapcsolatokat mutat, az alvó funkciótól egészen az önellátó tanyákig. A gazdasági és politikai tényezők, Nyíregyháza város hozzáállása és a helyi lakosok szemlélete, tevékenysége együttesen befolyásolják a helyzetüket. Napjainkra már nem csak a gazdálkodó tevékenység meghatározó. A tanyákat éltető erő az egyéni, családi életutak mellett a közösség ereje is, mely az egymásra utalt életmód következtében újra felértékelödik. A perifériás jelleg kihívásai mellet a rekreációs tevékenység, a turizmus lehetősége is mutatkozik. A tanyák sorsa eltérő irányokat mutat, szociológiai szempontból is szélsőséges helyzetekkel találkozhatunk, életképességüket változatos okok erősítik.
\end{abstract}

Kulcsszavak: tanyabokor, differenciálódás, civil szervezetek, kihívások

DOI: $10.19055 / \mathrm{ams} .2017 .8 / 25 / 5$

\title{
Bevezetés
}

A Nyíregyházától nyugatra elterülő tanyabokrok (1. ábra) jelentős mértékben magukon hordozzák a rendszerváltozás óta eltelt időszakban bekövetkező változásokat, településképi, szociológiai és egyéb területeken is. Elörebocsátom azt, hogy tanyák elsorvadásától (például Mohosbokor, Lakatosbokor) önálló aprófalvas jellegig (Mandabokor, Vajdabokor), vagy a városperemi kertvárosi részekkel való egybeolvadásig (Szélsőbokor, Salamonbokor) többféle fejlődési utat járnak be. Sokévi szakmai munka, lokálpatriótizmus és a média szerepe is hozzájárul, hogy napjainkra a tanyákon élő és a városban lakó tirpák leszármazottak identitástudata kialakul, megfelelő helyére kerül e jelző. A 2011. óta elérhető tanyafejlesztési programból összességében csekély mértékben részesültek. Meghatározó infrastrukturális fejlesztés az ipari terület érdekében történt. 


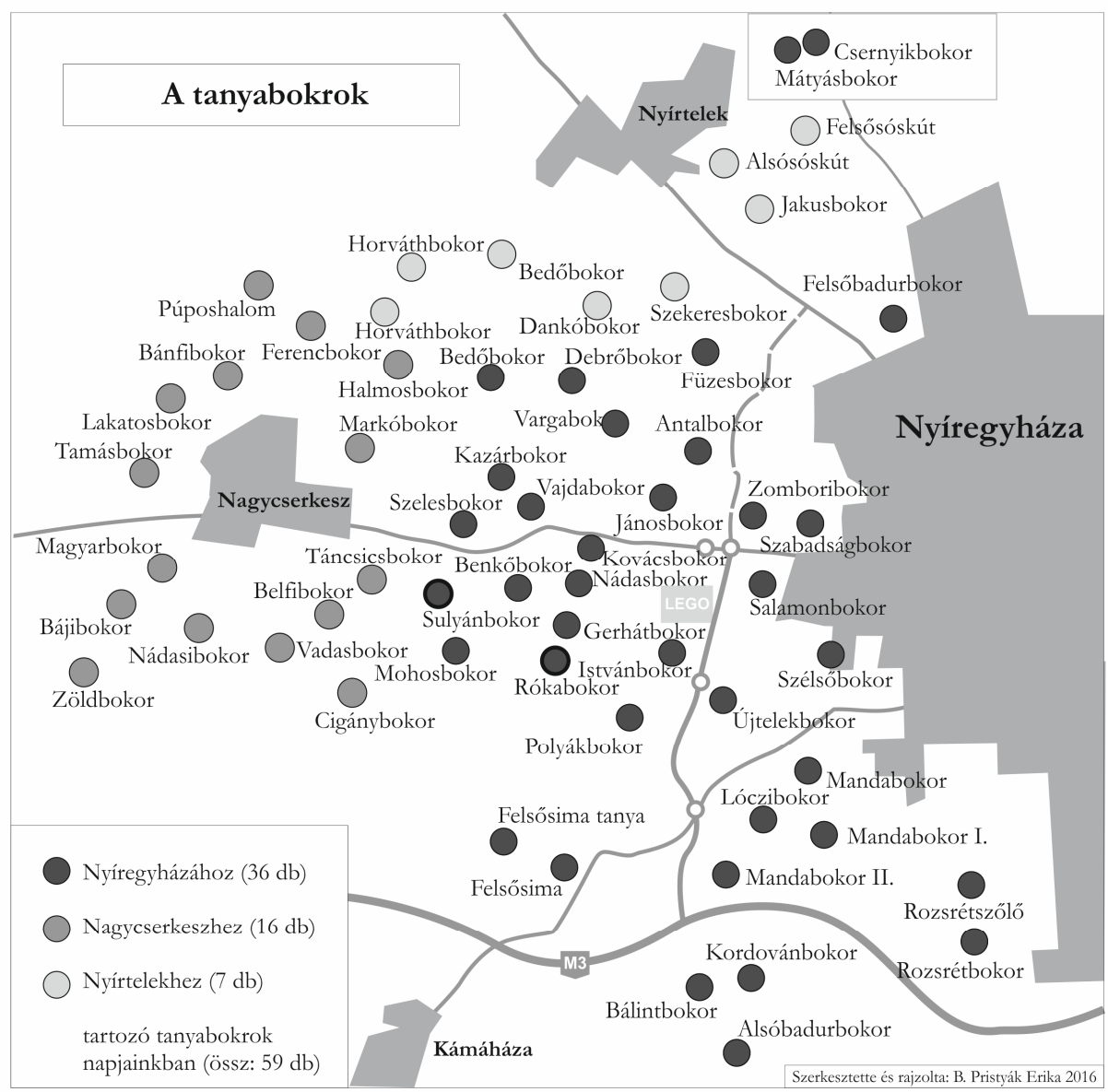

Forrás: Saját szerkesztés.

1. ábra A tanyabokrok elhelyezkedése, a fó útvonalakkal.

A földrajzi fekvés meghatározó helyzete, a gócterületek közelsége, de nem lényegtelen a településméret sem: a városoktól a kistelepülésekig haladva egyre kedvezőtlenebb foglalkoztatási és jövedelmi helyzetről, vagyis a települési lejtő müködéséröl tanúskodnak adatok. Mélyülő területi, gazdasági és társadalmi egyenlötlenségek, a szegénység, a területi és társadalmi hátrányok metszéspontján elhelyezkedő kistelepülések, kistérségek problémái hasonlóak (Kovács, Váradi szerk, 2013). Az aprófalvak sokaságát és a tanyákat érintő hasonló szakmapolitikai intézkedések, és az intézkedések hiányát is pótló spontán megnyilvánulások rajzolják ki egységesen a vidék társadalmi helyzetét. A „vidék” lehet szubjektív 
kategória, amennyiben a megyeszékhelyek kiemelkedő szigetként rajzolódnak ki a különböző társadalmi jellemzőket és folyamatokat bemutató térképeken (pl: jövedelmi viszonyok, iskolázottság, fiatalok aránya, stb). Ezek az adatok elfedhetik a tanyák problémáit, hiszen „csak” külterületekről van szó, nem önálló településtípus. A KSH alapos kutatásaiban is gyakran „magányos vagy csoportos beépítésü" területként jellemzik. Az adatokból (2. ábra) egyértelmüen kirajzolódik, hogy a hagyományos mezőgazdaság a lakosság ötödét érinti és a szolgáltatási jellegü ágazatokban dolgozik a foglalkoztatottak fele már ebben a településtípusban is. Mindezek összességében határozzák meg azokat a kihívásokat, amelyek napjainkban a bokortanyákat is érintik egy fejlődő, innovatív megyei jogú város közvetlen közelében.

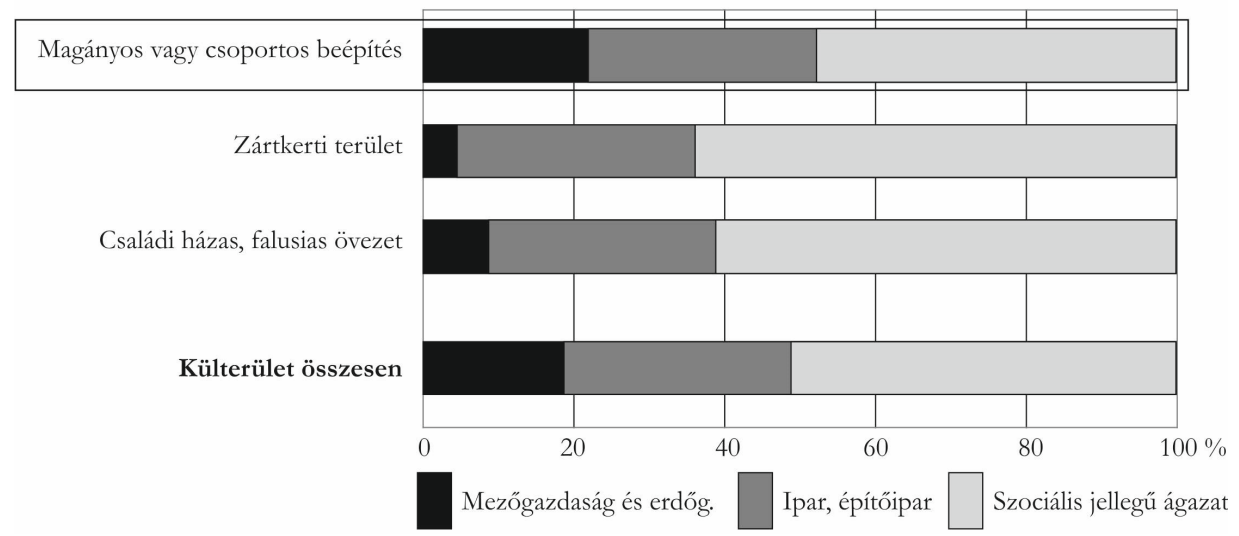

Forrás: KSH-2016.

2. ábra A külterületen élő foglalkoztatottak összevont nemzetgazdasági ágak szerinti összetétele a lakóövezet jellege szerint, 2011.

\section{Történeti áttekintés a tanyabokrok fejlödéséről}

A bokortanyák kialakulásához, a XVIII. század közepén egy tipikus alföldi betelepítéssel találkozunk: a hosszú török hódoltság és a Rákóczi-szabadságharc következében elnéptelenedett országunk ezen térsége is. Az Alföld egyéb területeihez hasonlóan Nyíregyháza földesurai is újratelepítették a határt, hosszas küzdelem árán szabadon gyakorolhatták evangélikus vallásukat is. Nem mérnökök jelölték ki a tanyák helyét, mint az Alföld más helyein, hanem a természetes felszíni adottságokat kihasználva, lehetöleg itatóhelyek körül, spontán megtelepedés útján jöttek 
létre az ideiglenes szállások, ezek lettek a későbbi a településmagok. A bokortanyák ősi formája a szállásföld, e föld a faluban lakó gazdák tulajdona volt. Mintegy száz éven keresztül tartozéktelepülésként, kettős szálláselv szerint müködtek a tanyák: a gazda a városban lakott, kint, főleg télen, csak a szolgálók maradtak. A tanyák fenntartása és fennmaradásuk elsősorban gazdasági okokra vezethetők vissza. Eleinte birtokközösségben éltek, a rokonok, nagycsaládok együtt kapták ki földjüket. Ha a kint élők nem akarták elveszíteni földjeiket, rétjeiket és járandóságaikat, akkor évröl évre elö kellett teremteni a bérletek összegét. A közösséget összekovácsoló, felelősségre szokató, önállósodást segítő, a takarékos megfontolt gazdálkodás hozzájárult a város fejlődéséhez (Kujbusné, 2003). A bokortanyás letelepedés formája összeegyeztette a tanyaelv és a földközösségi művelési forma, illetve a nyomásos gazdálkodás követelményeit, egyesítette mindezt, így maradt hosszútávon életképes.

A bokortanyák megerősödése a XIX. századra tehető. Az 1800-as évek első évtizedeiben a város lakossága jelentős anyagi áldozatok árán megváltotta magát a földesúri szolgáltatásoktól, a tanyák földje így a szabad parasztpolgárok magántulajdona lett, meghatározó esemény volt a jobbágyfelszabadítás: 1803-tól indult meg a kiköltözése a szállásföldekre. A XIX. század első negyedében véglegesen kiköltöző népesség teremtette meg a bokortanyák napjainkig meghatározó helyzetét. A szerkezetváltás, az intenzívebb szántó- és kertgazdálkodás az ideiglenes szállásokat az 1850-es évekre állandó lakhellyé és egyben üzemi központtá formálta át (Frisnyák, 2003). A társadalmi-gazdasági fejlődés 1753-tól az 1850-es évekig terjedő periódusában a többséget alkotó szlovák népesség gazdaság- és kultúraélénkítő szerepe alapozta meg a város növekedését és további elörehaladását. A „,bokor” elnevezés a XIX. század közepétől terjedt el. Először Sexty József, a város fömérnöke használja a bokorszállás nevet 1823-ban, egy 1827-ben tartott összeírásban 57 tanyacsoport szerepelt. Az első betelepítéstől számított egy évszázad elteltével erösödtek meg annyira a bokortanyák, hogy tanyai iskolák megnyitását kéri a lakosság, ami meg is történik az 1860-as évektől, addig a gyerekek a városban tanultak. Kezdetben szlovák nyelvű oktatás folyt, majd 1867-68-ban elrendelik a tanyákon is a magyar nyelv tantárgyi oktatását. A bokortanyák végleges meggyökeresedése, az építkezések számának növekedése, a településforma rögzülése a következő két nemzedék alatt valósult meg. Az 1910-ben végrehajtott népszámlálás idején 50 tanyabokorban 8519 lélek élt A lakosság nagy része végleg feladta a városi házát, teljes egészében kiköltözött a tanyákra gazdálkodni. Előzőleg még földbe mélyített házakban laktak, de a századforduló körül már többnyire vert falú házakban éltek, kalákában építkeztek.

A II. világháborút követő kényszerü lakosságcserét követő legnagyobb változások szintén felülröl irányítottan jelentkeztek. Az 1950-es évektől a falu- és tanyasorvasztó településpolitika hatására összevonni igyekeztek a tanyákat. A közigazgatási átrendezés következtében 3 nagyobb község alakult ki: Nagycserkesz, 
Nyírtelek, Kálmánháza. 1952-ben hozták létre Nagycserkeszt, a Nyíregyháza határában fekvő 18 tanyabokor egyesítésével, napjainkban is területének jelentős része külterület, melyet 16 bokortanya alkot. Hét bokortanyát a szintén önállóvá váló Nyírtelekhez csatoltak. Az 1970-es évektől elsősorban a város fejlődése és az infrastruktúra fejlesztésének hiánya következtében elköltözések jellemezték a tanyákat. Az időszak építkezésére jellemző kockaházakat azonban megtaláljuk a tanyákon is, többnyire egy portán a régi házzal. A leggyakoribb megoldás újra a kettős gazdálkodás volt: már a városban laktak, dolgoztak, de még megtartották a tanyasi házat és földet, ahol kiegészítő gazdálkodást folytattak, mely akkoriban jól jövedelmezett a munkahely mellett. A tanyák népessége így lassan elöregedett, az épületek karbantartásával sem mindenki törődött.

A következő jelentősebb változás a bokortanyák fejlődésében a belterületté nyilvánítás kérdése volt. Az 1980-as években a négy legnagyobb, főutak menti bokortanyát kiemelték. Mandabokor, Vajdabokor, Felsősima és Rozsrétszőlő ekkor lett belterület. Ezáltal is koncentrálták a népességet, a hatékonyabb infrastrukturális fejlesztések, szociális ellátás, iskolák összevonása miatt. Itt az építkezések száma növekedett, a beépítettségi arányok következtében falusias jellegüek lettek, Mandabokor, Rozsrétszőlő aprófalvakra emlékeztet, önálló településsé alakulás szándéka azonban nem alakult ki azóta sem, mert Nyíregyháza közelsége miatt ez nem indokolt. A rendszerváltozást követő időszakban egy évtizedes eltolódással indult meg újra kitelepülés. A környezet, a föld, a gazdálkodás felértékelödése a 2000-es évek elejére azonban már változatos, néha szélsőséges megoldásokat eredményezett. A társadalmi olló szétnyílását ekkor már a tanyák épületállományában is megfigyelhetjük, ami azóta is folytatódik.

\section{A bokortanyák helyzete napjainkban}

A tanyák társadalmi-gazdasági revitalizációjának alapja a rendszerváltozás óta eltelt évtizedek gazdasági változásai, az infrastrukturális fejlesztések lehetővé teszik az újraéledést. A tirpák hagyományok újraéledéséhez nagyban hozzájárultak a betelepítés 250. évfordulója alkalmából lezajlott rendezvények, kutatások. A 2000-es évek elején még zömében elsorvadó bokrokkal találkoztunk, mára ez megváltozott, az 1. táblázatban láthatjuk a népességszámot és az infrastrukturális változásokat. A tanyás térségek fejlődése előtt többféle út áll. Jövőjük az önkormányzati településpolitikától, az ott élők aktív településfejlesztésétől vagy paszszivitásától, lakóhelyük iránt érzett szeretetétől is függ.

A tanyákat és a várost mindig összekötötte az egymásrautaltság. Napjaink globalizált világában azonban a tanyákon élöknek nagyobb szüksége van a város 
nyújtotta szolgáltatásokra, mint a városnak a tanyai gazdálkodás biztosította ellátásra. Munkába és iskolába a városba járnak a tanyai lakosok, de emellett a szabadidejüket is szívesen töltik hasonlóan, mint a belterületen lakók. Az ezekhez szükséges intézmények hiányoznak a bokortanyákról, ennek következtében a mindennapos kapcsolat törvényszerü a városi és a tanyasi lakosság között, a tanyák közötti kapcsolatok is mérséklődtek. A városból is ingáznak dolgozók a bokortanyákon található munkahelyekre.

Ezek a problémák városunk stratégiai dokumentumaiban is megjelennek: a városrész fejlesztésének célja a bokortanyák lakó- és mezőgazdasági funkciójának erősítése, intenzív bekapcsolása a város helyi élelmiszerellátásába. $\mathrm{Az}$ infrastrukturális és (köz) szolgáltatási ellátottság javítása, valamint közösségi összefogás erősítése révén. További cél a városrész adottságaira épülő sajátos turisztikai célpontok kialakítása, fejlesztése, illetve új ipari fejlesztési terület kialakítása.

A legjelentősebb külterületi népességszám-növekedés a belterületi besorolásba került helyeken történt: Felsősima 450, Rozsrétszőlö 1220 fö, Manda-, Vajdabokor: 263 és 314 fö, Salamon-, Alsóbadur-, és Felsőbadurbokor népessége is meghaladja a 200 fót, ezeknek a tanyáknak egy része már szinte egybeolvadt a várossal. A legkevesebb lakosú bokortanyák: Mohos-, Kordován-, István- és Nádasbokor 10-20 fő közötti, Bedö-, Debrő-, és Szelesbokor 20-30 fő közötti lakosságszámú.

Általában mérséklődött az 1990-ig tartó népességfogyás, de az átlagtól nagy eltérések adódnak, összességében stagnál a népességszám, 2011. évi népszámlálási adatok alapján 7888 fö él bokortanyákon- ez a szám az összes, Nyíregyházához, Nyírtelekhez és Nagycserkeszhez tartozó tanyákon élők száma. A Nyíregyházához tartozó bokortanyai városrészben (ITS, Nyíregyháza) napjainkban mintegy 5200 fó él. A népesség megoszlása megegyezik a városi átlaggal (!): a 0-14 évesek aránya $16 \%, 15-59$ évesek aránya $65 \%$, és az idősebb korúak, 60- x évesek aránya $20 \%$. A város környékén - elfogadva a megyeszékhelyre becsült adatokat - hozzávetőlegesen 10 \% a romák aránya (Huszti, 2001). Polyákbokorban koncentrálódik, emellett Nagycserkeszen és környékén élnek nagyobb számban.

Jellemző a tanyák népességének kutatására, hogy átfogó vizsgálatok alkalmával, mint például a Nyíregyháza ifjúsága 2015 kutatás (Huszti, Takács, Hüse, 2016). kismértékben terjed rá figyelem. Ennek oka az össznépességen belüli alacsony arányuk is lehet.

A bokortanyákon, mint ahogy a város más külterületi részén is, mozaikos kép rajzolódik ki, nagy szélsőségekkel: elöregedő, sorvadó tanyákat és tehetős „,magánbirtokokat" is találunk. Egy átlagos népességszámú tanya lakosságszáma ma is hasonló, mint a XIX. század közepén, a kezdeti fejlődési időszakban: 35 és 188 fő közötti. A legnépesebb tanyák a városhoz vagy a fő közlekedési utakhoz közel esnek, a legkevesebb lakossal rendelkező bokrok elszórtan helyezkednek el. 


\begin{tabular}{|c|c|c|c|c|c|c|c|c|c|}
\hline Megnevezés & $\begin{array}{l}\text { Népes- } \\
\text { ség- } \\
\text { szám }\end{array}$ & $\begin{array}{l}\text { Laká- } \\
\text { sok } \\
\text { száma }\end{array}$ & $\begin{array}{l}\text { Ivóvíz- } \\
\text { hálózat }\end{array}$ & $\begin{array}{l}\text { Gáz- } \\
\text { háló- } \\
\text { zat }\end{array}$ & $\begin{array}{l}\text { Szenny- } \\
\text { víz }\end{array}$ & $\begin{array}{l}\text { Busz- } \\
\text { járat }\end{array}$ & $\begin{array}{l}\text { Köve- } \\
\text { zett út }\end{array}$ & $\begin{array}{l}\text { Szoc. } \\
\text { ellá- } \\
\text { tás }\end{array}$ & $\begin{array}{l}\text { Táv. a } \\
\text { kp.-tól } \\
\text { (km) }\end{array}$ \\
\hline Alsóbadurbokor & 264 & 88 & + & + & - & + & + & + & 11 \\
\hline Antalbokor & 71 & 35 & + & + & - & + & + & + & 6 \\
\hline Bálintbokor & 83 & 49 & + & + & - & + & + & + & 10 \\
\hline Bedőbokor & 28 & 15 & + & - & - & - & - & + & 11 \\
\hline Benkőbokor & 67 & 29 & + & + & + & + & + & + & 8 \\
\hline Csernyikbokor & 121 & 52 & Terv & + & - & - & - & - & 12 \\
\hline Debrőbokor & 23 & 16 & + & + & - & - & - & + & 10 \\
\hline Felsőbadurbokor & 239 & 141 & + & - & - & - & - & - & 8 \\
\hline Felsősima & 450 & 158 & + & + & - & + & + & + & 11 \\
\hline Felsősima & 241 & 103 & + & + & - & - & - & + & 13 \\
\hline Füzesbokor & 53 & 23 & + & + & - & - & - & + & 6 \\
\hline Gerhátbokor & 74 & 35 & + & + & + & + & + & + & 7 \\
\hline Istvánbokor & 16 & 12 & Terv & - & - & - & + & + & 6 \\
\hline Jánosbokor & 188 & 76 & + & + & + & + & + & + & 7 \\
\hline Kazárbokor & 70 & 34 & + & + & + & + & + & + & 8 \\
\hline Kordovánbokor & 14 & 16 & + & - & - & + & + & + & 11 \\
\hline Kovácsbokor & 55 & 28 & + & + & + & + & + & + & 7 \\
\hline Lóczibokor & 35 & 17 & + & + & - & + & + & + & 7 \\
\hline Mandabokor & 263 & 82 & + & + & + & + & + & + & 8 \\
\hline Mandabokor I & 153 & 64 & + & + & + & - & + & + & 7 \\
\hline Mandabokor II & 67 & 31 & + & + & + & - & - & + & 10 \\
\hline Mátyásbokor & 43 & 21 & - & + & - & - & - & - & 11 \\
\hline Mohosbokor & 10 & 5 & Terv & - & + & - & - & + & 7 \\
\hline Nádasbokor & 17 & 9 & + & + & + & - & - & + & 7 \\
\hline Polyákbokor & 146 & 38 & + & + & + & - & - & - & 8 \\
\hline Rókabokor & 40 & 24 & + & + & + & + & + & + & 9 \\
\hline Rozsrétszőlő & 1220 & 407 & + & + & + & + & + & + & 8 \\
\hline Rozsrétbokor & 42 & 13 & + & - & + & - & + & + & 8 \\
\hline Salamonbokor & 218 & 75 & + & + & + & + & + & + & 5 \\
\hline Sulyánbokor & 40 & 26 & + & + & + & + & + & + & 9 \\
\hline Szabadságb. & 88 & 38 & + & + & - & - & + & + & 4 \\
\hline Szelesbokor & 25 & 11 & + & + & - & - & - & + & 8 \\
\hline Szélsőbokor & 54 & 26 & + & + & - & + & + & - & 5 \\
\hline Újtelekbokor & 106 & 47 & + & + & + & + & + & + & 6 \\
\hline Vajdabokor & 314 & 97 & + & + & + & + & + & + & 7 \\
\hline Vargabokor & 128 & 63 & + & + & + & + & + & + & 8 \\
\hline Zomboribokor & 67 & 33 & + & + & + & + & + & + & 5 \\
\hline Összesen: & 5133 & 2037 & 32 & 30 & & 21 & 25 & 30 & - \\
\hline
\end{tabular}

Forrás: Saját adatgyüjtés és szerkesztés.

1. táblázat A nyíregyházi bokortanyák népességszáma, infrastrukturális jellemzői. 
A 3. ábrán a bokortanyák állapotát mutatom be, túlfejlett, azaz a kertvárossal öszszenőtt, vagy falusias jellegü bokroktól az elsorvadó, kiüresedő tanyákig minden állapotot megfigyelhetünk.

$\mathrm{Az}$ iskolai végzettség és foglakoztatás elmarad a városi átlagtól, de sokkal kedvezőbb képet mutat, mint a megelőző évtizedben. Legfeljebb általános iskolai végzettséggel rendelkezők és rendszeres munkajövedelemmel nem rendelkezők aránya az aktív korúakon belül még mindig magas: 15\% (a városi átlag 8\%). A városba járnak régóta a gyerekek, két autó jellemző a családokra (inkább két régebbi, mint egy új). A rozsréti iskolán kívül elszórtan a városi iskolákba járnak a gyerekek, ezt a szabad iskolaválasztás lehetővé teszi. Különórákra, sportra, szórakozásra és egyéb tevékenységekre járás a család anyagi helyzetétől függ, nem pedig attól hogy hol laknak.

Âltalános Iskola Roszsrétszőlőn 8 évfolyamon, 140 fővel müködik. Az óvodai felügyelet nagyobb tanyaközpontokban van biztosítva: Mandabokor, Felsősima, Rozsrétbokor, Felsősimán, a kihasználtság megközelíti a 100\%-ot. A gyermekek szállításához tömegközlekedést is igénybe lehet venni.

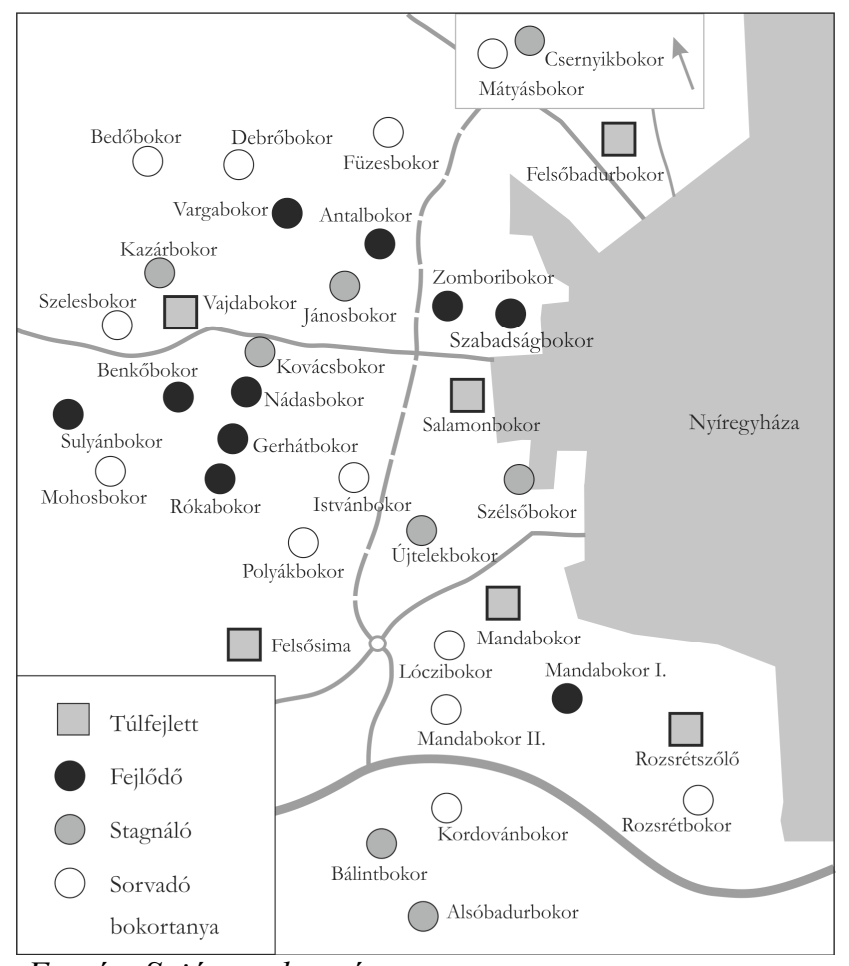

Forrás: Saját szerkesztés.

3. ábra A nyíregyházi bokortanyák állapotának egyszerüsített ábrázolása. 
A foglalkoztatottak aránya a 15-64 éves népességen belül 48\% (a városi átlag $56 \%$ ), a gazdaságilag nem aktív népesség aránya lakónépességen belül $56 \%$ (a városi átlag $52 \%, I T S$ ). Többségében a városban dolgoznak a tanyán élők, emellett egyéni gazdálkodás, vállalkozás a jellemző. Napjainkra elterjedtebb, hogy egyik tanyáról a másikra mennek dolgozni, főleg idénymunkák, tavaszi ültetések, kapálások, szüretek, betakarítások alkalmával, de állandó foglalkoztatás is megfigyelhető így. A munkanélküliek aránya közelítőleg $20 \%$.

A tanyás térségekben a házak komfortossága rosszabb, mint a városban. A szennyvízhálózat kiépítése erre is megoldást kínál, bár sok esetben nem gazdaságos. Az ingatlanok többsége házi ülepítőt használt a csatornázás előtt. A külterületi településrészek több mint 2/3-ában szervezett szemétgyüjtés és szállítás történik.

A szuburbanizációs folyamatok vonatkozásában is meghatározó terület. A Nyíregyházát körülvevő településgyürü túlságosan távolinak bizonyult - különösen nyugati, déli és délkeleti irányban - így a városhoz közelebb, igazgatási határain belül alakult ki az a szuburbia, mely szervesen kapcsolódik a város magterületéhez (Kókai, Pristyák, 2012).

A kiköltözések oka többféle lehet. Nagy Zsuzsa, a Debreceni Egyetem hallgatója szakdolgozatában vizsgálta 2014-ben ezt a kérdést. Az első helyen a családi érzelmi kötődés áll, az ő esetükben feltételezhetően az ott élő rokonok, barátok miatt történik a költözés. A kertes házas környezet, a jó levegő, mint vonzó tényező a második helyen áll 33\%-al. A megkérdezettek 15\%-a azért költözött lakóhelyére, hogy mezőgazdasági termelő tevékenységbe kezdjen. Napjainkban azt tapasztalom, hogy a családok kezdik újra felfedezni a földmüvelésben rejlö lehetőségeket, és a városvezetés is támogatja a családi gazdaságok müködését. Sokan azért költöznek ki a tanyasi térségbe, mert ott olcsóbb a megélhetés, mint a városokban. A válaszadók 13\%-a ilyen okból választotta a bokortanyákat. Az egyéb választ adók indoka házasságkötés miatt a párjuk lakhelyére költözés volt (Nagy, 2014). A város számára jelentős lakóterületi tartalékokat jelentenek a bokortanyák.

Az elmúlt évtized legjelentősebb szociális területủ változása a tanyagondnoki szolgálat bevezetése volt, mely mára szervesen hozzátartozik a kint élők mindennapjaikhoz, a rászorulók és igénylők megszerették ezt a szolgáltatást. Az ellátás 2000 óta jól kiépült, jelentős szerepe volt ebben az evangélikus egyháznak. A tanyagondnoki szolgáltatás a legjobb ellátási forma. Jelenleg 34 tanyát érint a szolgáltatás, négy fö tanyagondnok tevékenykedik. 


\section{Civil és egyházi szervezetek jelentősége a tanyákon}

Kutatásaim előtt azt gondoltam, hogy a tanyák lakossága még jobban összertartó közösség, mint egy-egy városi kisebb lakóközösség, de már itt is eltérö tapasztalataim vannak. A védelmi funkció még erős, figyelik az idegeneket, szólnak egymásnak, de egyéb közös tevékenység ritka. Elsősorban egy-egy személyhez, vagy családhoz kötődik, ahol van tanai élet, közös együttlétek, emellett a civil és egyházi szervezetek hozzák össze a lakosokat. Helyi szerveződésű „tanyanapot” is tartanak (Mandabokor, Rozsrét, Sulyánbokor, Magyarbokor), vagy valamilyen cél, érdek miatt jönnek össze a „tanyasi” emberek.

A civil kezdeményezések célja az is, hogy segítse a helyi termelők és fogyasztók közötti kapcsolatot, ezáltal növelje a helyben előállított élelmiszerek fogyasztását. Nem a tanyákhoz kapcsolódik, de segíti az ott élők munkáját is. Egyre több tanyáról kapcsolódnak be ebbe: Újtelek-, Sulyán-, Mohos-, Salamon-, Manda-, Bedőbokor, kínálják kisállataikat, késztermékeiket, zöldség- és gyümölcs termékeiket. Több tevékenysége jelentős a terület természeti értékeinek (Szigetvári, 2015 ) és a természeti értékkel összehangolt gazdálkodás erősítésében.

Az evangélikus egyház tevékenysége jelenleg is meghatározó a közösség összetartozásában. A város vallási összetételéből jól kitünik, hogy napjainkra az evangélikusok aránya nagyon alacsony lett: 7\% (KSH, 2011). A legnagyobb csökkenést az evangélikusok számában: a XIX. századi asszimiláció, a háborúk okozta változások, a vegyes házasságok nagy száma és a szocializmus időszakában történtek, ismert okok miatt. A vallási összetétel ma már a bokortanyákon élők körében is vegyes, az evangélikusok aránya hozzávetőlegesen 60-80 \%. A bokortanyák két egyházközségbe tartoznak. Mandabokorban az új evangélikus többfunkciós közösségi házat 2013. tavaszán vette használatba a gyülekezet, melyet folyamatosan megtöltenek, egyebek mellett ifjúsági órákkal, rendezvényekkel. Alapítványuk a Segítség háza a tirpák utódokért a fiatalokat fogja össze. A nyugatra eső városrészt és tizenhat tanyabokrot, valamint szórványait a Nyíregyháza-Kertvárosi Ágostai Hitvallású Evangélikus Egyház látja, mely 1992-ben önállósult a nyíregyházi gyülekezetből. Istentiszteletet rendszeresen van emellett Vajda- Benkő- Salamon- és Rókabokorban, Rozsrétszőlőn. Csendesnapokat, családi napokat, aratási hálaadó napokat is rendszeresen tartanak. Az egyházak vallási tevékenysége mellett napjainkra a szociális ellátás és a közösség összetartása területén is meghatározó. 


\section{Néhány tanya közelebbrö1}

Néhány, egymás közelében elhelyezkedő tanyát: Sulyán-, Benkő-, Gerhát- és Rókabokort, elsősorban a lakosság összetételét és részben a településszerkezetét részletesebben viszgáltam. A helyszíni munka mellett a helyi tanyagondnokok is segítségemre voltak a kutatásban.

A négy tanya bevezető utakon jól megközelíthetően, a városközponttól 6-9 km távolságban helyezkedik el (3. ábra). Ezek a tanyák is a XVIII. század közepén a Károlyi-féle újjátelepítés során jöttek létre, eredetileg szállásföldek voltak, majd elsősorban a gazdálkodásban és életformában bekövetkezett változások miatt megerősödtek, iskolákat az 1860-as évektől indított az evangélikus egyház. Népességszámuk a két világháború között és a hatvanas években volt a legnagyobb, együttesen mintegy 550 fö (2. táblázat). A szocializmus időszakának intézkedései ellenére fennmaradtak a bokortanyák, az elmúlt évtizedben revitalizáció jellemzi őket. Napjainkban népességszámuk alacsonyabb, egyenként 40 fő körüli, összesen mintegy 150 fö. Az 1960-as években elért maximális népességszámhoz képest közel negyedére esett vissza a lakosság száma, azonban a rendszerváltás környékén bekövetkező mélypontból újra növekedésnek indultak. Sulyán- és Gerhátbokor fiatalodó lakossága is bizonyítja, hogy a szuburbanizációba intenzíven bekapcsolódnak a tanyák. Az infrastruktúra fejlődése (Benkőbokorban müködő szociális intézmény, szennyvízcsatorna, szelektív hulladékgyüjtés, mozgó könyvtár) is jelzi, hogy nemcsak szociális kényszerből költöznek ki a tanyákra. Sulyán- és Rókabokor szép, védett tanyaszerkezete további turisztikai fejlődést is magában rejt. A bokortanyákon a megközelíthetőség és a körülmények javulása és a gazdálkodók, vállalkozók száma biztosítja, hogy újra többé váljanak ezek a tanyák, mint városkörnyéki alvótelepülés.

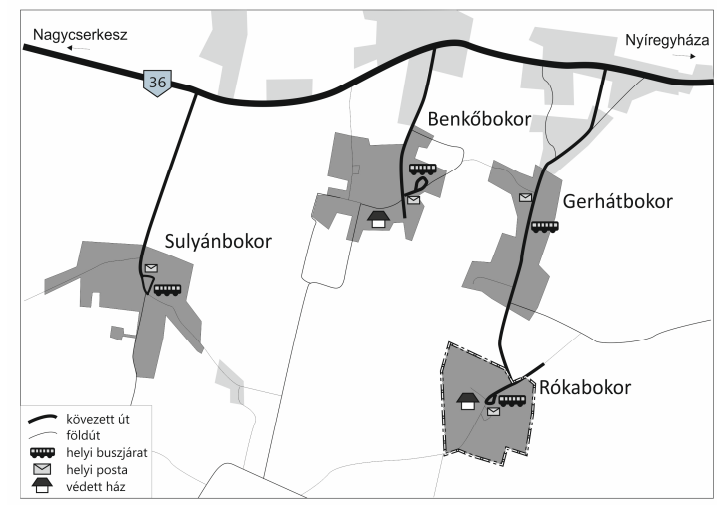

Forrás: Saját szerkesztés.

3. ábra Sulyán-, Benkö-, Gerhát- és Rókabokor elhelyezkedése. 


\begin{tabular}{|l|r|l|l|r|r|}
\hline & $\begin{array}{l}\text { Sulyán- } \\
\text { bokor }\end{array}$ & $\begin{array}{l}\text { Benkö- } \\
\text { bokor }\end{array}$ & $\begin{array}{l}\text { Gerhát- } \\
\text { bokor }\end{array}$ & $\begin{array}{l}\text { Róka- } \\
\text { bokor }\end{array}$ & $\begin{array}{l}\text { Összesen } \\
\text { (4 tanya) }\end{array}$ \\
\hline $0-14 \dot{e} v$ & 9 & 5 & 13 & 1 & 28 \\
\hline $15-25 \dot{e} v$ & 1 & 4 & 3 & 1 & 9 \\
\hline $26-45 \dot{e} v$ & 12 & 7 & 6 & 5 & 30 \\
\hline $46-62 \dot{e ́ v}$ & 9 & 13 & 17 & 6 & 45 \\
\hline $63 \dot{e} v$ felett & 8 & 13 & 6 & 10 & 37 \\
\hline$\ddot{O}$ ssz. 2015 & $\mathbf{3 9}$ & $\mathbf{4 2}$ & $\mathbf{4 5}$ & $\mathbf{2 3}$ & $\mathbf{1 4 9}$ \\
\hline 2011 & 40 & 72 & 97 & 40 & 249 \\
\hline 1991 & 58 & 70 & 63 & 46 & 237 \\
\hline 1960 & 149 & 129 & 148 & 122 & 548 \\
\hline 1920 & 177 & 131 & 135 & 101 & 554 \\
\hline
\end{tabular}

Forrás: KSH és saját gyüjtésalapján.

2. táblázat Sulyán-, Benkő-, Gerhát- és Rókabokor népességszáma (fö) korösszetétel alapján 2015-ben, összlakosság 1920-, 1960-, 1991-, 2011- és 2015-ben.

\section{A bokortanyákat érintő legújabb kihívások}

A tanyabokrok funkciója részben megváltozott, a kint élők életmódja nagy eltéréseket mutat, jelentősen differenciálódtak a tanyák. Kutatásaim alapján négy alaptípusba sorolom a nyíregyházi bokortanyákat: túlfejlett tanya, fejlődő, stagnáló és sorvadó bokortanyák (2. ábra), ezek nagyjából egyenletes arányban oszlanak el a területen és szám szerint is hasonló arányban vannak, de szélsőséges, mozaikos tanyaképekkel találkozunk. A népességszám a városhoz közeli, vagy gyorsan, jól megközelíthető egykori tanyabokrokban növekszik, mely ma már inkább falusias vagy kertvárosias tanyaképet mutat.

A tanyákat éltető erő napjainkban az egyéni, családi életutak mellett a közösség ereje is, mely napjainkban egyre inkább felértékelődik.

Néhány jellemző eset:

- a múlt, a hagyomány ereje, (pl. Sulyánbokorban),

- a tanyai életmód szeretete (pl. Gerhátbokorban),

- a gazdasági viszonyok és a családi gazdálkodás jelentősége (pl. Vargabokor),

- az infrastruktúra javulásával a belvárostól eltérő, de kényelmes lakókörnyezetet igénylők szándéka megvalósulhat: városi lakosként kellemes természeti környezetben élhetnek, közel a „,nagyvárosi” szolgáltatásokhoz. (pl. Salamon-, Antalbokor),

- a helyi közösség ereje, a civil szerveződések akarata, lehetőségei meghatározóak (pl. Magyarbokor), 
- az egyházak szociális tevékenysége a hagyományos lelkészi irányítású öszszetartó erőn túl (pl. Benkőbokor).

Napjaink szükségszerüen bekövetkezö kihívásai a tanyák számára:

- a nem mezőgazdasági jellegü vállalkozások megjelenése, bővülése,

- a szadabidős, turisztikai, rekreációs szolgáltatások elszigetelt jelenségek maradnak,

- érdekütközések, pl: városszéli kertváros vagy még tanya,

- megfelelő méretü földterület, telephely, de még közös telken a lakóházzal,

- farm vagy tanya típusú gazdálkodás,

- $\quad$ szélsőséges környezeti, építészeti megoldások találkozása.

A tanyák sorsát külső és belső tényezők alakítják. A tanyáktól független tényezők, a társadalmi, politikai, gazdasági tényezők távol esnek az érdekérvényesítő lehetőségektől. Nyíregyháza város hozzáállása, és az adott helyi tényezők együttesen alakítják egy-egy porta és így egy-egy tanyabokor életét. A tanyák elrendeződése változatos, az azonban kirajzolódik, hogy a város közelsége, a fő közlekedési utak és az infrastruktúra fejlettsége meghatározó a tanyák fejlödésében. A tipizálás azért is veszélyes, mert felgyorsult, mobilis életünkben évröl évre is változik a helyzet. Pusztuló és innovatív tanyákkal is találkozunk, mindazonáltal a tanyabokrok fennmaradása és fenntartása nem lehet kétséges.

\section{Felhasznált irodalom}

1. Bánszki H. (2012): A csehszlovák-magyar lakosságcsere előkészítése Nyíregyházán. In: Buhály A. - Reszler G. -Szoboszlay Gy. (szerk) Falak és választóvonalak a történelemben. Terminus könyvek 1. Kiadja a Nyíregyházi Főiskola Történettudományi és Filozófiai Intézete, pp 241-253.

2. B. Pristyák E (2011): A bokortanyák differenciálódása az elmúlt 20 évben, In: Geográfiai folyamatok térben és időben. Tanulmánykötet Dr. Hanusz Árpád 65. születésnapja tiszteletére, szerkesztette: Kókai S. Nyíregyháza, pp. 45-61.

3. Bácskainé Pristyák E. (2014): Életképes bokortanyák, Kiadja a Nyíregyházi Föiskola p132

4. Csatári B. (2004): Tanyai kaleidoszkóp. MTA RKK Alföldi Tudományos Intézet, Kecskemét p192.

5. Csatári B. (2004): Homokhátság 2004. Szembesítés, lehetőségek, teendők. Kecskemét: MTA RKK Alföldi Tudományos Intézet, Kutatási jelentések 1. 
füzet. A tanyás térségek környezete. Kecskemét: MTA RKK Alföldi Tudományos Intézete,. 6-14. o.

6. Duró A. (2005): A tanyai társadalom. In: Tanyakutatás, 2005. Kutatási jelentések, 3. füzet.

7. A homokhátsági tanyák társadalma és szociális problémái. Kecskemét: MTA RKK Alföldi Tudományos Intézete, 2005. 2-16. o.

8. Csatári B.- Farkas J.- Kovács A. (2016): Egy alföldi tanyás mezőváros terének dinamikus változásai Kecskemét példáján. http://www.regscience.hu:8080/ jspui/bitstream/11155/1175/1/csatari_alfoldi_2016.pdf

9. Kovács K. -Váradi M. (2013): Hátrányban, vidéken. Argumentum kiadó, p384.

10. Frisnyák S. (2003): A szlovák telepesek kultúrtáj- és gazdaságfejlesztő tevékenysége, Nyíregyházán (18-19. század). In. Nyíregyháza, Előadások a város újratelepítésének 250. évfordulóján. Kiadja a Nyíregyházi Főiskola Földrajz Tanszéke, Nyíregyháza pp 87-100.

11. Huszti É. (2001): A Nyíregyháza környéki tanyavilág az ezredfordulón. In: Szabolcs-Szatmár-Beregi Szemle 36:(2) pp. 153-165.

12. Huszti É. - Takács P. - Hüse L. (2016): A "Nyíregyháza Ifjúsága 2015" kutatás módszertana, ACTA MEDICINAE ET SOCIOLOGICA 7:(20-21) pp. 211-256. (2016)

13. Kókai S.- B. Pristyák E. (2012): Az agglomerálódás és az szuburbanizáció jellemzői a Nyíregyházi településeggyüttesben. In: Településföldrajzi tanulmányok 2012/2, szerk. Csapó T., Kiadja a Nyugat-magyarországi Egytem, Szombathely, pp. 87-103.

14. A külterületen élők társadalmi gazdaségi jellemzői, KSH 2016. p 60.

15. Kujbusné Mecsei É. (2003): Nyíregyháza önkormányzata (1753-1848). Kiadja a Szabolcs-Szatmár-Bereg Megyei Levéltár, II. közlemények 28. Nyíregyháza 2003 p. 324.

16. Nagy Zs. (2014): A nyíregyházi bokortanyák társadalmi - gazdasági helyzetének bemutatása, jövőjének vizsgálata geoinformatikai eszközök segítségével. Debreceni Egyetem TTTK, Földtudományi Intézet diplomamunka p54.

17. Nagy G.-Dudás G.-Bodnár G. (2016): „Megfogyva bár...” Egy tanyafelmérés tanulságai Békés megyében. In: Tér és társadalom. 30. évfolyam 1. szám. pp. 93-111. doi:10.17649/TET.30.1.2721

18. Szigetvári Cs. (2015): Barátságos bokortanyák - Kalauz a Nyíregyháza környéki bokortanyás és tanyás térség természeti értékeihez, térképmelléklettel. E-misszió Természet- és Környezetvédelmi Egyesület kiadványa. Nyíregyháza $\mathrm{p} 24$.

19. Interjúk, terepbejárás. 


\section{Bácskainé Dr. Pristyák Erika}

Ph.D. Nyíregyházi Egyetem, Turizmus és Földrajztudományi Intézet főiskolai docense

4400 Nyíregyháza, Sóstói út 31/b.

pristyak.erika@nye.hu 